\title{
Comparative Study on the Development of Main Language Institutions in the Philippines
}

\author{
Lili Xu \\ The Southern Base of Confucius Institute Headquarters \\ Xiamen University \\ Xiamen, China
}

\author{
Kehua $\mathrm{Yu}^{*}$ \\ College of International Culture \\ South China Normal University \\ Guangzhou, China
}

\begin{abstract}
The major language institutions have established branches in the Philippines. They have all about the same mission, that is, promote the development of their own languages in the Philippines and deepen the exchange and understanding between two cultures. They hold different characteristics in organization patterns, content, promoting channels and service, based on which this paper makes a comparative study of the development of these institutions in the Philippines and attempts to analyze their advantages and disadvantages, in a bid to draw some enlightenment for the development of Confucius Institutes in the Philippines.
\end{abstract}

Keywords-language institutions; the Philippines; Confucius Institute; cultural communication

\section{INTRODUCTION}

The Philippines is an archipelagic multi-ethnic country with rich resources and favorable geographical setting. It had a population of at least 100 million. As a member of the ASEAN and APEC, the Philippines is one of the largest economies in southeast Asia and has a prominent regional strategic position, making it one of the key development areas for the world's major language institutions. At present, almost all of the world's major language institutions have set branches in the Philippines. Although their purposes and core tasks in the Philippines are generally the same, their development in the Philippines is characterized by historical, economic, social, cultural and linguistic policies.

This paper mainly sheds light on the language institutions that have cooperated with the Department of Education of the Philippines in SPFL before May, 2019. They are The Alliance Française (since 1920 in the Philippines), Goethe-institute (since 1961 in the Philippines), Instituto Cervantes (since 1994 in the Philippines), The Japan Foundation (since 1996 in the Philippines), Korean Cultural Center (since 2011 in the Philippines) and Confucius Institutes (since 2006 in the Philippines). As English serves as the official language in Philippines, this paper also covers the British Council (since 1978 in the Philippines).

Institutions like The Alliance Française, Goethe-institute and British Council have a long history and have run in Philippines for a long time with rich popularization experience

This research was financially supported by Humanities and Social Science Foundation of Ministry of Education of China "The Strategies of the popularization of Mandarin Chinese in the Philippines under 'One Belt One Road'” (Grant No.: 18YJC740118) and Xiamen University Graduate Field Fund Survey "The Intercultural Teaching Competence of Chinese Language Teachers Survey”(Grant No.: 2018GF024). and mature operation. Whereas, organizations like Instituto Cervantes, The Japan Foundation Manila (JFM), Confucius Institutes (CIs) and Korean Cultural Center (KCC) emerge late but develop fast.

\section{ORganization MANAgEMENT AND OPERATION MODE}

The above-mentioned language institutions all have the governments of the countries that they belong to participated in the management and operation. The ways and degrees of the participation vary from country to country. Such institutions as Goethe-institute, Instituto Cervantes, JFM and KCC have been dominated by their countries officially. Goethe-institute takes on the Germany teaching and cultural exchanges as the official cultural communication agency of Germen government and the research institution. It has launched cooperation with Philippine Department of Education and cultural organizations. Instituto Cervantes in Manila was announced by the Spanish princess named Dona Elena and received support in such aspects as expenditure, teaching personnel and equipment. It is created to strengthen the Spanish culture spreading in Southeast Asia. The Japan Foundation belongs to the Japanese Ministry of Foreign Affairs and is an important platform for Japan to develop internationally. [1] JFM conducts activities and exchanges as an educational and cultural institution of Japanese embassy in Philippines. KCC is under the joint leadership of the ministry of culture of the republic of Korea, the ministry of culture, sports and tourism of the republic of Korea and the embassy of the republic of Korea in the Philippines. It has maintained a close relationship with the arts and culture department of the Philippines.

By contrast, British Council, The Alliance Française and CIs are not as official as those counterparts. British Council, though, has the Royal Charter,[2] makes more efforts in dilute the official nature, because the American colonial period left a deep colonial trace on the development of English in Philippine society. It also builds their own image of social services and public welfare through a series of community projects such as the development of child protection plans, concerning the peace maintaining process in Medan Island, etc. The Alliance Française in Manila has the independent corporate capacity with the freedom to develop. Though it is unofficial, the French government has supported it in both fund and policies, and has established a long-term partnership with Embassy of France in Manila, Philippines, French schools and French companies in the Philippines, alumni association etc. CIs in Philippines run 
under the cooperation among Confucius Institute Headquarters, the host school in Philippines and the undertaking school in China. At present, four Confucius Institutes have been opened in Philippines. They are CI at Ateneo de Manila University (2006), CI at Bulacan State University (2009), CI at Angeles University Foundation (2010) and CI at University of the Philippines (2015). They are all located in the universities of the Philippines, relying on the resources of the universities, and their enrollment and development plans are carried out under the overall planning framework of the universities of the Philippines. The headquarters of Confucius Institutes will provide some support to CIs in terms of operating funds, teachers and courseware resources. This mode of development enables CIs to effectively alleviate the "incompatibility" in the early stage of establishment, quickly acquire a student base, and at the same time enhance the comprehensive strength of Philippine universities in providing local social services.

\section{BUSINESS SCOPE AND SPECIFIC CONTENT}

Focusing on language teaching and cultural exchange, the main business of each institution centers are on language teaching, examination service, cultural exchange, library business and social service.

TABLE I. MAIN BUSINESS OF THE LANGUAGE INSTITUTIONS

\begin{tabular}{|c|c|c|c|c|c|}
\hline Institutions & Language teaching & $\begin{array}{c}\text { Examination } \\
\text { service }\end{array}$ & Library service & Cultural exchange & Social services \\
\hline $\begin{array}{l}\text { The Alliance } \\
\text { Française }\end{array}$ & \begin{tabular}{|l|} 
Standardized online and \\
offline French courses \\
for different groups; \\
professional curriculum; \\
workshops assisting \\
language teaching; \\
teacher training
\end{tabular} & DELF; DALF & $\begin{array}{l}\text { Reading materials and } \\
\text { multimedia materials; open } \\
\text { reading rooms and } \\
\text { children's reading corners; } \\
\text { reading exchange activities }\end{array}$ & $\begin{array}{l}\text { Music; film; art, seminar; French } \\
\text { culture; short program for the } \\
\text { Artist’s short-term residence in } \\
\text { France }\end{array}$ & $\begin{array}{l}\text { Translation; venue rental; employment; } \\
\text { Quebec immigration service; restaurant } \\
\text { operation }\end{array}$ \\
\hline $\begin{array}{l}\text { Goethe- } \\
\text { institute }\end{array}$ & $\begin{array}{l}\text { Standardized online and } \\
\text { offline German courses; } \\
\text { professional curriculum; } \\
\text { German teacher } \\
\text { promotion training; } \\
\text { SPFL plan }\end{array}$ & $\begin{array}{l}\text { TestDaF; Goethe- } \\
\text { Test PRO }\end{array}$ & $\begin{array}{l}\text { German books; newspapers } \\
\text { and multimedia materials; } \\
\text { open reading room; } \\
\text { NetLibrary }\end{array}$ & $\begin{array}{l}\text { Music; architecture; fashion; } \\
\text { design; dance; drama; film; } \\
\text { literature; visual arts; } \\
\text { photography; communication in } \\
\text { photography and video games; } \\
\text { academic conference }\end{array}$ & $\begin{array}{l}\text { Translation project (support German } \\
\text { authors to publish books in foreign } \\
\text { languages); Immigration services; } \\
\text { study in Germany }\end{array}$ \\
\hline $\begin{array}{l}\text { British } \\
\text { Council }\end{array}$ & $\begin{array}{l}\text { Standardized online and } \\
\text { offline English courses } \\
\text { for different groups; } \\
\text { professional curriculum; } \\
\text { teacher training }\end{array}$ & $\begin{array}{l}\text { IELTS; TKT; } \\
\text { vocational } \\
\text { qualification } \\
\text { examination; } \\
\text { college exam; } \\
\text { Aptis test }\end{array}$ & $\begin{array}{l}\text { Open multimedia learning } \\
\text { room; online English } \\
\text { resources; app } \\
\text { downloading }\end{array}$ & $\begin{array}{l}\text { Film; radio station; visual arts; } \\
\text { literature and art; creative } \\
\text { industries; global digital } \\
\text { marketing campaign; academic } \\
\text { exchange workshop }\end{array}$ & $\begin{array}{l}\text { Social entrepreneurship research; } \\
\text { teaching survey; local entrepreneurship } \\
\text { support and business opportunities } \\
\text { development; Enterprise leader } \\
\text { training; training of media personnel; } \\
\text { Peace process promotion workshop; } \\
\text { study and exchange programs; child } \\
\text { care program }\end{array}$ \\
\hline $\begin{array}{l}\text { Instituto } \\
\text { Cervantes }\end{array}$ & $\begin{array}{l}\text { Standard Spanish } \\
\text { course; professional } \\
\text { curriculum; teacher } \\
\text { training; SPFL plan; } \\
\text { AVE global courses }\end{array}$ & DELE; SIELE & $\begin{array}{l}\text { Open library with more } \\
\text { than 20,000 kinds of books, } \\
\text { periodicals and multimedia } \\
\text { resources; access to } \\
\text { database network like } \\
\text { MLA, ULRICH and CSIC; } \\
\text { information consulting on } \\
\text { Spain or Latin America } \\
\end{array}$ & $\begin{array}{l}\text { Theater; dance; music; literature; } \\
\text { art; architecture; cuisine; } \\
\text { Academic exchange and } \\
\text { discussion on multiple subjects }\end{array}$ & $\begin{array}{l}\text { Spanish and Latin American culture } \\
\text { spreading; work with different } \\
\text { institutions, companies and public and } \\
\text { private organizations in different } \\
\text { countries; provides meeting space for } \\
\text { experts in various fields }\end{array}$ \\
\hline $\begin{array}{l}\text { The Japan } \\
\text { Foundation }\end{array}$ & \begin{tabular}{|l|} 
Japanese language \\
curriculum; Culture \\
courses; Language \\
courses for registered \\
nurses and nursing staff, \\
Japanese teacher \\
training; SPFL plan
\end{tabular} & JLPT & $\begin{array}{l}\text { Reference Center; } \\
\text { Information Center; open } \\
\text { reading room; audio visual } \\
\text { area }\end{array}$ & $\begin{array}{l}\text { Provide support to local Japanese } \\
\text { research institutions in the aspects } \\
\text { of conferences, researchers, } \\
\text { information, training, } \\
\text { publications, etc.; train experts in } \\
\text { Japanese studies; conduct } \\
\text { academic discussions and } \\
\text { intellectual dialogue; film; art } \\
\text { exchanges }\end{array}$ & $\begin{array}{l}\text { Approve JFM regional grant program, } \\
\text { Asia central regional funding scheme to } \\
\text { financially support for Japan- } \\
\text { Philippines exchanges and cultural } \\
\text { cooperation projects; establish } \\
\text { PHILFEJA }\end{array}$ \\
\hline $\begin{array}{l}\text { Confucius } \\
\text { Institute }\end{array}$ & $\begin{array}{l}\text { Chinese language } \\
\text { teaching and culture } \\
\text { teaching; language } \\
\text { teaching for special } \\
\text { group; SPFL plan } \\
\end{array}$ & $\begin{array}{l}\text { HSK/HSKK; } \\
\text { YCT; BCT }\end{array}$ & $\begin{array}{l}\text { Open reading room; } \\
\text { Confucius Institute Online }\end{array}$ & $\begin{array}{l}\text { Film; photography; festival; } \\
\text { "Chinese Bridge” competition; } \\
\text { cuisine; music; traditional art; } \\
\text { cultural exchange; lecture }\end{array}$ & $\begin{array}{l}\text { Study in China; translation; China } \\
\text { information consulting }\end{array}$ \\
\hline $\begin{array}{l}\text { Korean } \\
\text { Cultural } \\
\text { Center }\end{array}$ & $\begin{array}{l}\text { Online and offline } \\
\text { Korean language } \\
\text { courses; spouse visa } \\
\text { language course; } \\
\text { Kickboxing; K-POP; } \\
\text { song; dance; cuisine; } \\
\text { Painting courses; SPFL } \\
\text { plan }\end{array}$ & TOPIK & $\begin{array}{l}6000 \text { pieces of books and } \\
\text { media resource, open } \\
\text { multi-function hall }\end{array}$ & $\begin{array}{l}\text { Cultural caravan at the local } \\
\text { university; dance; diet activities; } \\
\text { traditional culture; music; Korean } \\
\text { tidal wave; film and television }\end{array}$ & $\begin{array}{l}\text { Study in Korea; Korean art group; } \\
\text { Korean language teaching resources; } \\
\text { translation; Korean news in Manila } \\
\text { reports; Korean news; Manila news } \\
\text { reports; cooperation with the technical } \\
\text { education and skills development } \\
\text { agency of the Philippines }\end{array}$ \\
\hline
\end{tabular}


From the business scope of various institutions, it can be seen that these language institutions present some obvious trends in the development of language teaching and cultural activities. First of all, language institutions are no longer the sole subject of activities. They come to seek social collaborators, and harness their advantages and characteristics to promote the cultural activities and enhance the professionalism of activities. Government agencies, enterprises, art institutions, schools, media and mass organizations may participate in the activities to achieve win-win cooperation with language institutions. Secondly, the content is increasingly close to contemporary events covering broad topics. In this way, the language education and cultural activities of the institution have a wide audience base. As the contents are close to the current life, it greatly increases the attraction of the institution. Thirdly, in the business service, they realize to use space and resources to increase the audience's experience opportunities and optimize the sense of experience. For example, carry out interactive cultural activities for participants to contact and exchange ideas. Open characteristic restaurants. Provide resources for local projects, etc.

\section{Business Promotion Channels AND Service Modes}

For these language institutions, the language teaching and cultural exchange in the Philippines belong to the activities of cross-cultural communication. In order to form local influence, it is necessary to use a variety of communication channels comprehensively to transform their cross-cultural ability and expand their influence through "we media", mass communication and interpersonal communication. [3] Therefore, major language institutions attach great importance to shaping their cultural images by combining their own cultural characteristics and advantages. For example, The Alliance Française launches cultural activities that are closely related to the art exchanges between The Philippines and France. It provides Filipino artists with opportunities to get close to French art forms and connotations through short-term residence in France. Goethe-institute focuses on academic research, emphasizing the importance of German as an academic language in academic exchanges around the world, and provides a platform for high-level academic dialogue in many fields. With rich experience in language teaching and cultural communication, British Council focuses on creating rich online and offline teaching materials and courses for various groups. Meanwhile, it also focuses on building its image of social service in Philippine society. Instituto Cervantes, on the basis of language teaching, pays special attention to the dissemination of Latin American culture, and strives to create a channel for the exchange, search and translation of Latin American cultural information with abundant resources and strong Internet connectivity. JFM encourages local Japanese research in the Philippines. Provide various support to local Japanese research institutions in terms of conferences, researchers, materials, training, publications, etc., focus on training Japanese research experts, conduct academic discussions, intellectual dialogue, film, art exchange, etc., and provide financial support for Japan-Philippines exchange programs through a number of funding schemes. CIs put much emphasis on promoting the integration of Chinese language education into the Philippine national education system and providing educational support for the learning of Chinese in the local area. KCC takes advantage of the "Korean wave" and makes it become a popular fashion in the Philippines by means of Cultural caravans, theatrical performances and shooting short films of Korean language and Cultural learning by Korean stars.

In addition, with the development of informatization, language institutions have realized the role of network resources and network communication channels in promoting their own business development. Therefore, The Alliance Francaise, Goethe-institute, British Council, Instituto Cervantes and KCC have all developed online and offline language courses. At the same time, language institutions take measures to build "we media" and mass communication platforms, set up interactive communities, information introduction platforms and activity display platforms on Facebook, twitter, Instagram and other media, for institutional publicity, information exchange and student achievement sharing. JFM didn't open the online course, but has built a website with diversified modules like art and culture communication, the Japanese education, and scientific communication studies in Japan, library and resources, which display the institution in an allround way, providing convenient consulting and communication channels, and facilitating its own propaganda. In terms of publicity and service based on the network and wemedia, CIs falls behind other language institutions. Four Confucius Institutes in the Philippines at present all have the self-built media, but only the CI at Ateneo DE Manila University provides application interface and use path for enrollment, course description, the promotion and students interaction,[4] the other three Confucius Institutes self-built media and Internet publicity are given priority to with the information publicity, lack of practical application value.

\section{ENLiGHTENMENT TO THE DEVELOPMENT OF CONFUCIUS INSTITUTES IN THE PHILIPPINES}

In recent years, CIs in the Philippines have become an important brand and platform for Chinese language teaching in the Philippines. However, compared with other time-honored language and culture institutions, there is still room for improvement in terms of activity forms, participants and activity levels. The main recommendations are as follows.

\section{A. Introduce market-oriented model to seek internal motivation for the sustainable development of CIs.}

At present, the four Confucius Institutes all run under the cooperation between Chinese and Philippine universities, and are located in Philippine universities. Rely on the local universities to carry out activities under their overall development plan, with relatively weak independence and freedom. These institutes offer course for free, except for the fee-paying courses offered by CI at Ateneo DE Manila University in the educational site of Makati. In contrast, other language promotion agencies that are independent institutions possess a high degree of freedom to carry out activities, and all courses have standard fees. The profits are used to maintain and improve the operation of the institutions and continue to carry out follow-up activities, forming a virtuous circle. After a long period of development, some language institutions have 
already formed a mature industrial model. This experience can be the reference in the process of moving towards sustainable development. It is necessary to consider introducing marketization mode to some projects to explore profit mode and seek internal motivation for the sustainable development of CIs.

\section{B. Attach importance to the exploration and development of social partners and achieve "win-win" situation}

The activities and influence building of various language institutions cannot be carried out without the support of local society. Suitable social partners will enable these language agencies to get the support of resources, manpower and channels in cultural exchange activities, thus getting twofold results with half the effort. [5] At the same time, the language advantage of the institute and the function of the information platform will serve these collaborators, generating positive effects. Therefore, CIs in local areas should fully recognize the significance to invite and encourage social partners to join the activity organizations as subjects. For example, they can establish customized talent training cooperation projects with local enterprises to cultivate professional talents that are proficient in Chinese. Carry out teaching exchange activities and seminars with Chinese schools, share new teaching ideas and methods, and provide support to them with teaching materials, teachers and teaching methods, so as to jointly improve local Chinese teaching level.

\section{Expand business scope and depth, while providing language teaching and language services.}

The four Confucius Institutes still remain as a relatively pure language teaching institution as their activities are mainly, in essence, the language training and academic exchanges. [6] However, years of exploration and development have helped other language institutions transform their functions, namely, gradually take language teaching as a means of language services. With the deepening of cooperation and exchanges between China and the Philippines in various fields, the demand for Chinese language learning and Chinese language services in the Philippines has greatly increased. CIs should make good use of this opportunity to explore more service functions such as translation, consultation and information connection based on the previous development.

\section{Use modern information technology to serve the functional construction of CIs.}

In the digital media era, industries all rely on digital media for transformation and upgrade. CIs themselves should also conform to the trend to make full use of big data platform and the information technologies. Firstly, they can integrate Chinese language resources and social resources, focus on building high-quality digital learning materials and realize multimedia information services and online digital education. Secondly, the network platform can be utilized with the local business development and exchanges of CIs to build an international interdisciplinary expert information base and think tank serving the in-depth exchanges and cooperation between China and the Philippines. Thirdly, develop a big data platform integrating staff recruitment, training, teaching support, Chinese learning and communication, as well as information storage and sharing, to prepare for the multifunctional construction of the CI.

\section{CONCLUSION}

To sum up, through the comparison of language institutes of different countries in the Philippines, a more comprehensive understanding in CIs characteristics, advantages, and drawbacks have been obtained. The enlightenment in operation, activity organization, business content and forms has been concluded for the development of CIs. Currently, China and Philippines have deepened their cooperation in various fields, raising the applicable value of Chinese language in local society. CIs should grasp the opportunity to upgrade business.

\section{REFERENCES}

[1] Song Jia, The Cultural Mission of Eight National Language-Spreading Organizations in the Era of Globalization in an Internationally Comparative Perspective, Comparative Education Review,2013,8 (98). (In Chinese)

[2] British Council in the Philippines, https://www.britishcouncil.ph/about

[3] An Ran, He Guohua, On the Evaluation Dimension of Intercultural Communication Influence of Confucius Institutes, Guangxi Social Sciences, 2017, 3 (180-181). (In Chinese)

[4] CI at Ateneo de Manila University, http://ateneoconfucius.squarespace.com/

[5] Cao Diefeng, Comparative Analysis on the Operational Models and Decision-Making Mechanisms of Language Promotion Organizations in Different Countries, Journal of Social Science of Hunan Normal University, 2014, 1 (147) .(In Chinese)

[6] Zhan Chunyan, Li Manna, Sustainable Development of Confucius Institutes: Indicators, Models and Prospects, Journal of South China Normal University(Social Science Edition), 2014, 1 (80-81). (In Chinese) 